\title{
Study of Anti-inflammatory Effect of CopA3 Peptide Derived from Copris tripartitus
}

Hyeon-Jeong Kim ${ }^{1,2}$, Dong-Hee Kim³, Jin-Young Lee, Jae-Sam Hwang ${ }^{5}$, Joon-Ha Lee ${ }^{5}$, Seul-Gi Lee', Hyeon-Guk Jeong ${ }^{1}$ and Bong-Jeun $\mathrm{An}^{1}{ }^{*}$

${ }^{1}$ Department of Cosmeceutical Science, Daegu Haany University, Daegu 712-715, Korea

${ }^{2}$ Institute of Techndogy, Herbnoori, Daegu 702-062, Korea

${ }^{3}$ Korea Promotion Institute for Traditional Medicine Industry, Gyeongsan 712-260, Korea

${ }^{4}$ Department of Herbal Cosmetic Science, Hoseo University, Chungnam, 336-795, Korea

${ }^{5}$ Department of Agricultural Biology, National Academy of Agricultural Science, Suwon 441-100, Korea

Received October 31, 2012 /Revised November 20, 2012 / Accepted January 3, 2013

\begin{abstract}
The objective of this study was to evaluate the effect of the synthetic CopA3 peptide of Copris tripartitus on skin inflammation. Regulatory mechanisms of cytokines and nitric oxide (NO) are involved in the immunological activity of RAW 264.7 cells. Tested cells were treated with different concentrations of CopA3 and further cultured for an appropriate time after lipopolyssacharide (LPS) addition. During the entire experimental period, 5, 25, 50, and $100 \mu \mathrm{g} / \mathrm{ml}$ of CopA3 had no cytotoxicity. At these con-

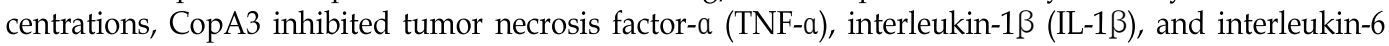
(IL-6). CopA3 also inhibited the expression of inducible NO synthase (iNOS) and cyclooxygenase-2 (COX-2). CopA3 inhibited the activity of iNOS and COX-2 by $41 \%$ and $59 \%$, respectively, at $100 \mu \mathrm{g} /$ $\mathrm{ml}$. In addition, CopA3 reduced the release of inflammatory cytokines including TNF- $\alpha$, IL-1 $\beta$, and IL-6. These results suggest that CopA3 may have significant effects on inflammatory factors and that it may be a potential anti-inflammatory therapeutic agent.
\end{abstract}

Key words : Anti-inflammatory, cyclooxygenase-2 (COX-2), inducible NO synthase (iNOS), CopA3, cytokine, Copris tripartitus

\section{서 론}

염증 반응은 생체나 조직에 물리적 작용이나 화학적 물질, 세균 감염 등의 어떠한 기질적 변화를 가져오는 침습이 가해 질 때 그 손상 부위를 수복 재생하려는 기전이며[8], 염증 반응 을 유발시키는 매개 물질로 활성산소(free radicals), 산화질소 (nitric oxide, NO), prostaglandin 등이 있다[24]. 일단 자극이 가해지면 국소적으로 염증성 성분과 같은 혈관 활성 물질이 유리되어 혈관 투과성이 증대되면서 염증을 유발하지만 지속 적인 염증반응은 도리어 점막손상을 촉진하고, 그 결과 일부 에서는 여러 질환을 발생시키는 원인이 된다[22]. 대식세포는 선천면역뿐만 아니라 획득면역 등 다양한 숙주반응에 관여하 여 항상성 유지에 관여하는 것으로 알려져 있으며, 염증반응 시에는 nitric oxide $(\mathrm{NO})$ 와 cytokine을 생산하여 감염초기에 생체방어에 중요한 역할을 한다[7]. NO의 합성 효소는 eNOS,

\footnotetext{
*Corresponding author

Tel : +82-53-819-1429, Fax : +82-53-819-1429

E-mail : anbj@dhu.ac.kr

This is an Open-Access article distributed under the terms of the Creative Commons Attribution Non-Commercial License (http://creativecommons.org/licenses/by-nc/3.0) which permits unrestricted non-commercial use, distribution, and reproduction in any medium, provided the original work is properly cited
}

$\mathrm{nNOS}, \mathrm{iNOS}$ 가 있는데, 이 중 iNOS는 칼슘의 농도에 상관없 이 대식세포에서 TNF-a, IL-1 $13, \mathrm{IFN}-\gamma$ 와 같은 염증성 자극에 의해 유도되는 것으로 알려졌으며, 특히 LPS 처리시 다량 생 성되는 것으로 알려졌다. TNF- $a$ 는 염증과 면역반응의 중요한 매개물질이며, 다양한 세포의 성장과 분화를 조절하는 것으로 알려졌다. 또한 세포에 독성을 일으키고, 혈관 형성, 골 흡수, 혈전 생성을 촉진하고 lipogenetic 대사를 억제하는 것으로 알 려졌다[1].

곤충은 동물군 중에서 가장 많은 생물군으로서, 전 세계적 으로 180 만 종이 서식하고 있고, 우리나라에서만 1만 2천 종이 나 서식하는 것으로 알려져 있다. 곤충은 생물 다양성이 매우 풍부하며, 환경에 따라서 이 곤충의 다양성이 결정되고 이에 관련된 여러 가지 곤충 유래의 생리활성 물질의 양과 질이 다양하게 변화된다. 최근에는 새로운 기능성을 갖는 약용곤충 을 발견, 상용화, 사육화, 보급화 함으로서 농가의 수익을 보장 하고 새로운 식의약품으로 개발이 활발히 진행되고 있는 추세 이다[17, 18].

소똥구리류는 목초지에서 우분을 지하로 운반하는 작용을 하며, 이러한 우분을 발생원으로 하여 파리의 발생 억제, 토양 의 비옥화와 물리성 개선, 우분과 함께 배설된 가축내부기생 충 방제 등의 효과가 있다[2,3]. 또한 소똥구리가 활동한 토양 
에 식물체의 생장촉진 등의 효과가 있어 생태계에 있어 매우 중요한 경제 곤충의 하나로 꼽히고 있다[5]. 최근 국립농업과 학원에서는 애기뿔소똥구리를 이용하여 의약품 소재를 개발 하기 위하여 다양한 실험을 진행하고 있다 $[6,9,10,11]$. 본 연구에서는 이러한 효능을 가진 애기뿔소똥구리에서 분리된 코프리신 펩타이드 유도체 CopA3를 이용하여 항염 효과 및 염증에 관련된 다양한 단백질 발현 양상을 측정하여 기초자료 로 활용하고자 한다.

\section{재료 및 방법}

\section{재료}

본 실험에 사용한 합성 펩타이드 CopA3는 자동화 된 solid-phase peptide synthesizer (Pioneer Applied Biosystems, Foster, CA)를 이용하여 AnyGen (Kwang-ju, Korea)사에서 9 $8 \%$ 이상의 순도로 합성하였고, $0.01 \%$ acetic acid에 녹여 사용 하였다[9].

\section{시약 및 기기}

세포 배양액인 dulbeco's modified eagle medium (DMEM), fetal bovine serum (FBS), streptomycin penicillin 등의 세포배양용 시약들은 invitrogen사(Carlsbad, CA, USA) 에서 구입하였다. 실험에 사용된 시약 중 sodium dodesyl sulfate (SDS), acrylamide, bisacrylamide는 Bio-rad사(Hercules, CA, USA)에서 구입하였고, NP-40, protease inhibitor, RIPA buffer, griess reagent 등은 Sigma Chemical Co. (St. Louis, $\mathrm{MO}, \mathrm{USA}$ )에서 구입하였다. 실험에 사용된 1 차 항체에는 iNOS BD bioscience (Sanjose, CA, USA)와 COX-2 cayman (Ann arbor, MI, USA)를 사용하였으며, $\beta$-actin과 2차 항체인 anti-rabbit Ig-G horseradish peroxidase (HRP)-conjugated antibody는 Santa cruz사(CA, USA)에서 구입하였다. $\mathrm{PGE}_{2}$ 측 정을 위한 ELISA kit는 R\&D systems Inc. (Minneapolis, MN, $\mathrm{USA}$ )에서 구입하여 실험에 사용하였다.

\section{세포배양}

마우스의 대식세포주인 Raw 264.7 cell은 한국세포주은행 (KCLB)에서 분양 받았으며, 세포배양을 위해 $10 \% \mathrm{FBS}$ 과 $1 \%$ penicillin-streptomycin을 포함하는 DMEM 배지를 사용하였 다. 세포는 $37^{\circ} \mathrm{C}, 5 \% \mathrm{CO}_{2}$ 조건에서 배양하였다.

\section{MTT assay에 의한 세포 생존율 측정}

애기뿔소똥구리에서 분리된 합성 펩타이드 CopA3에 대한 세포 독성 측정은 MTT 방법으로 분석하였다. Raw 264.7 cell $5 \times 10^{4}$ cells $/ \mathrm{ml}$ 를 96 well plate에 분주하고 CopA3를 농도 별 $(5,10,25,50,100,500 \mu \mathrm{g} / \mathrm{ml})$ 로 24시간 동안 처리하였다. Well당 $20 \mu \mathrm{l}$ 의 MTT용액을 첨가하여 $37^{\circ} \mathrm{C}, 5 \% \mathrm{CO}_{2}$ incubator
에서 4 시간 동안 반응시킨 후, ELISA reader를 이용하여 540 $\mathrm{nm}$ 에서 흡광도의 변화를 측정하여 대조군에 대한 세포생존 율을 백분율로 표시하였다.

\section{Nitric oxide 생성량 측정}

$\mathrm{NO}$ 의 농도는 배양액 내의 nitrite 농도를 griess reagent를 이용하여 측정하였다. Raw 264.7 cell은 DMEM 배지를 이용 하여 $5 \times 10^{5}$ cells $/ \mathrm{ml}$ 로 조절한 후 6 well plate에 접종하고, $5 \%$ $\mathrm{CO}_{2}$ incubator에서 24시간 전 배양하였다. 세포에 $1 \mathrm{\mu g} / \mathrm{ml}$ 의 LPS를 처리하고 1 시간 뒤에 농도별로 CopA3를 처리하여 24 시간 배양하였다. 배양액의 상층액을 얻은 후 griess 시약과 반응 시킨 후 ELISA reader로 $540 \mathrm{~nm}$ 에서 흡광도를 측정하여 $\mathrm{NO}$ 생성율을 백분율로 표시하였다.

Western blot을 이용한 inducible NO synthase (iNOS), cyclooxygenase-2 (COX-2) 활성 측정

iNOS protein 활성 측정을 확인하기 위하여 대식세포주인 Raw 264.7 cell은 DMEM 배지를 이용하여 $5 \times 10^{5} \mathrm{cells} / \mathrm{ml}$ 로 조절한 후 $100 \mathrm{~mm}$ cell culture dish에 접종하고, $5 \% \mathrm{CO}_{2}$ incubator에서 24시간 전 배양하였다. 세포에 $1 \mu \mathrm{g} / \mathrm{ml}$ 의 LPS를 처리하고 1 시간 뒤에 $5,25,50,100 \mathrm{\mu g} / \mathrm{ml}$ 의 CopA3를 처리하 여 24시간 배양 한 후 배지를 제거하고 phosphate buffer saline (PBS)로 2번 세척해 준 후, lysis buffer를 이용하여 단백질 을 추출한 후 원심 분리하여 상등액을 취하였다. 상등액을 bradford assay로 단백질 농도를 정량 한 후 $10 \%$ SDS-PAGE 를 시행하고, 전개된 단백질을 nitrocellulose membrane으로 이동시켰다. 이 membrane을 $5 \%$ skim milk로 1시간 동안 blocking하고, 1 차 항체 $(1: 1,000)$ 를 희석하여 $4^{\circ} \mathrm{C}$ 에서 over night한 다음, TBST로 10 분 간격으로 3 회 세척하고, 각각의 2차 항체를 1:1,000으로 희석하여 실온에서 2시간 동안 상온에 서 반응시켰다. 다시 TBST로 10 분간 3 회 세척 후 ECL용액으 로 반응시켜 LAS 4000 chemiluminescence detection system (Fuji, Tokyo, Japan)을 이용하여 현상 및 정량을 하였다.

\section{TNF- $a, I L-1 \beta, I L-6$ 생성량 측정}

세포배양액 내의 TNF-a, IL-13, IL-6 생성량은 ELISA kit를 이용하여 측정하였다. Raw 264.7 cell은 DMEM배지를 이용하 여 $5 \times 10^{5}$ cells $/ \mathrm{ml}$ 로 조절한 후 6 well plate에 접종하고, $5 \%$ $\mathrm{CO}_{2}$ incubator에서 24시간 배양하였다. 세포에 $1 \mu \mathrm{g} / \mathrm{ml}$ 의 LPS를 처리 한 뒤 1 시간 후에 CopA3를 처리하여 24시간 배양 한 후 배양배지를 취하여 TNF-a, IL-13, IL-6를 측정하였다.

\section{통계처리}

모든 실험은 3회 반복하여 측정하였고, 그 결과는 평균값 \pm 표준편차로 나타냈으며 통계적 분석은 SPSS 10.0 프로그램 을 이용하여 각 처리구간의 유의성 $(p<0.05,0.01)$ 검증을 위해 
분산분석(analysis of variance, ANOVA) 후 tukey test로 다중 비교를 실시하였다.

\section{결과 및 고찰}

\section{Raw 264.7 cell에 대한 독성}

마우스 대식세포인 Raw 264.7 cell에 대한 CopA3의 세포독 성을 확인하기 위하여 MTT assay를 수행하였다. CopA3를 5, $10,25,50,100,500 \mu \mathrm{g} / \mathrm{ml}$ 농도로 24 시간 동안 처리한 결과 $100 \mathrm{\mu g} / \mathrm{ml}$ 의 농도까지는 독성이 나타나지 않았지만, $500 \mathrm{\mu g} /$ $\mathrm{ml}$ 의 농도에서는 세포의 생존율을 $95 \%$ 감소 시켰다(Fig. 1). CopA3는 $100 \mathrm{\mu g} / \mathrm{ml}$ 이하의 농도에서는 세포독성이 낮아 세 포의 생존율에 영향을 주지 않는다는 사실을 확인할 수 있었 다. 즉, CopA3의 항염증 효과가 단순한 세포의 사멸에 의한 세포 염증성 매개물질의 생성억제가 아니라 CopA3의 고유한 효과라는 점을 의미한다.

\section{Nitric oxide (NO) 생성억제 효과}

$\mathrm{NO}$ 는 체내 방어기능, 신호전달 기능, 신경독성, 혈관 확장 등의 다양한 생리기능을 가지고 있으며, 3 종류의 NOS (neuronal NO synthase (nNOS), endothelial NO synthase (eNOS), inducible NO synthase (iNOS))에 의해 합성된다. 이 들 NOS 중 $\mathrm{iNOS}$ 에 의한 $\mathrm{NO}$ 생성이 절대적으로 많으며 이는 병리적으로 중요한 작용을 한다[23]. LPS 자극에 의해 발현된 $\mathrm{iNOS}$ 는 많은 양의 NO를 생성하게 되며, 이에 의한 세포독성 은 염증반응, 세포의 돌연변이 및 종양발생 등에도 관여하는 것으로 알려져 있다. 염증반응과 관련된 조직 손상에서 $\mathrm{NO}$ 와 $\mathrm{iNOS}$ 의 발현이 증가되어 있음이 보고되어 있다[15, 16, 21].

$\mathrm{NO}$ 생성에 대한 CopA3의 효과를 알아보았다. 생성된 NO 양을 griess 시약을 이용하여 세포배양액 중에 존재하는 $\mathrm{NO}_{2}^{-}$

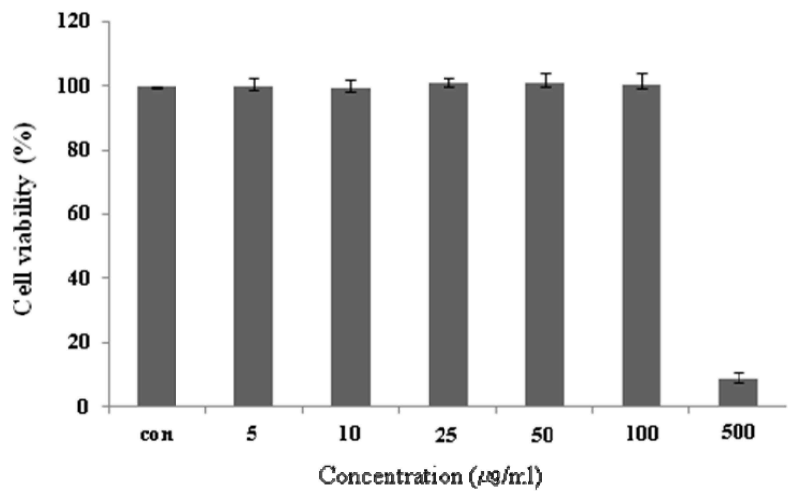

Fig. 1. Cell viability of CopA3 on Raw 264.7 cell. Raw 264.7 cells were treated with $5,10,25,50,100,500 \mu \mathrm{g} / \mathrm{ml}$ of CopA3 dissolved in media for $1 \mathrm{hr}$ prior to the addition of LPS $(1 \mu \mathrm{g} / \mathrm{ml})$, and the cells were further incubated for $24 \mathrm{hr}$. Data represent the mean \pm S.D. with eight separate experiments. Data represent the mean \pm S.D. with three separate experiments.
의 형태로 측정하였다. 그 결과 Raw 264.7 cell에 LPS를 처리한 후 CopA3를 처리한 NO 생성량의 변화는 Fig. 2에 나타내었 다. LPS 처리 후 NO 생성량은 정상세포에 비하여 약 4 배 이상 증가되었다. CopA3는 $50 \mu \mathrm{g} / \mathrm{ml}$ 의 $35 \%$ 이상의 감소율을 나타 내었으며, $100 \mu \mathrm{g} / \mathrm{ml}$ 의 농도에서는 $80 \%$ 이상의 $\mathrm{NO}$ 생성 저 해를 일으키는 것을 확인할 수 있었다.

\section{TNF- $a,\|L-1 \beta\| L-$,6 생성 억제 효과}

대식세포는 동물 체내 모든 조직에서 분포하는 면역세포로 서 세균이나 이물질을 탐식 제거하며, IL-13, IL-6, TNF-a 등의 염증 매개 물질들을 분비하여 초기 염증 반응에 주요 역할을 담당 한다 $[7,13]$. 특히, TNF- $a$ 는 염증반응에 있어서 중요한 역할을 하며 macrophage와 mast cell 등에서 분비되며, LPS반 응의 주요 매개체로서 내재면역에 있어서도 중요한 역할을 하며 만성 염증 반응과도 관련되어 있다[14]. IL-1 $\beta$ 는 T-cell의 활성화, B-cell의 성숙, NK cell의 activity를 활성화 하며, IL-6 는 림프구를 활성화시켜 항체생산을 증가시키는 것으로, IL-6 의 level은 염증성 병변에서 항상 증가하는 것으로 보고되고 있다[4]. 본 실험에서 LPS는 TNF-a, IL-13, IL-6의 생성을 증가 시켰지만 CopA3 처리한 결과 TNF-a는 $60 \%$ 생성 억제를 IL-1 $\beta, \mathrm{IL}-6$ 는 각각 $50 \mu \mathrm{g} / \mathrm{ml}$ 의 농도에서 $50 \%, 55 \%$ 의 생성 억제 효과를 나타내었다(Fig. 3). 일반적으로 LPS는 macrophage에 작용하여 TNF-a, IL-1ß, IL-6의 생성 분비를 촉진시켜 염증반 응을 유도하지만 CopA3는 이 세 가지의 cytokine을 유의성 있게 억제하였다.

iNOS, COX-2의 단백질 발현 저해 효과

$\mathrm{iNOS}$ 는 평소에는 세포 내에 존재하지 않으나 일단 유도되

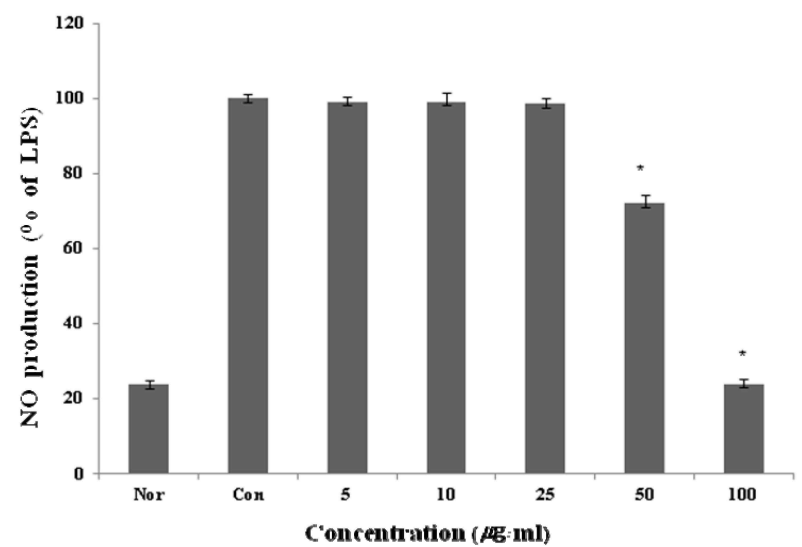

Fig. 2. Inhibitory effects of CopA3 on the production of nitric oxide Raw 264.7 cells. Raw 264.7 cells were cultured with LPS $(1 \mu \mathrm{g} / \mathrm{ml})$ in the presence or absence of CopA3 for $24 \mathrm{hr}$ to determine the level of NO. Nor: LPS not induced group, Con: LPS induced group. The data represent the mean $\pm S D$ of three separate experiments (significant as compared to control. ${ }^{*} p<0.05$ ). 

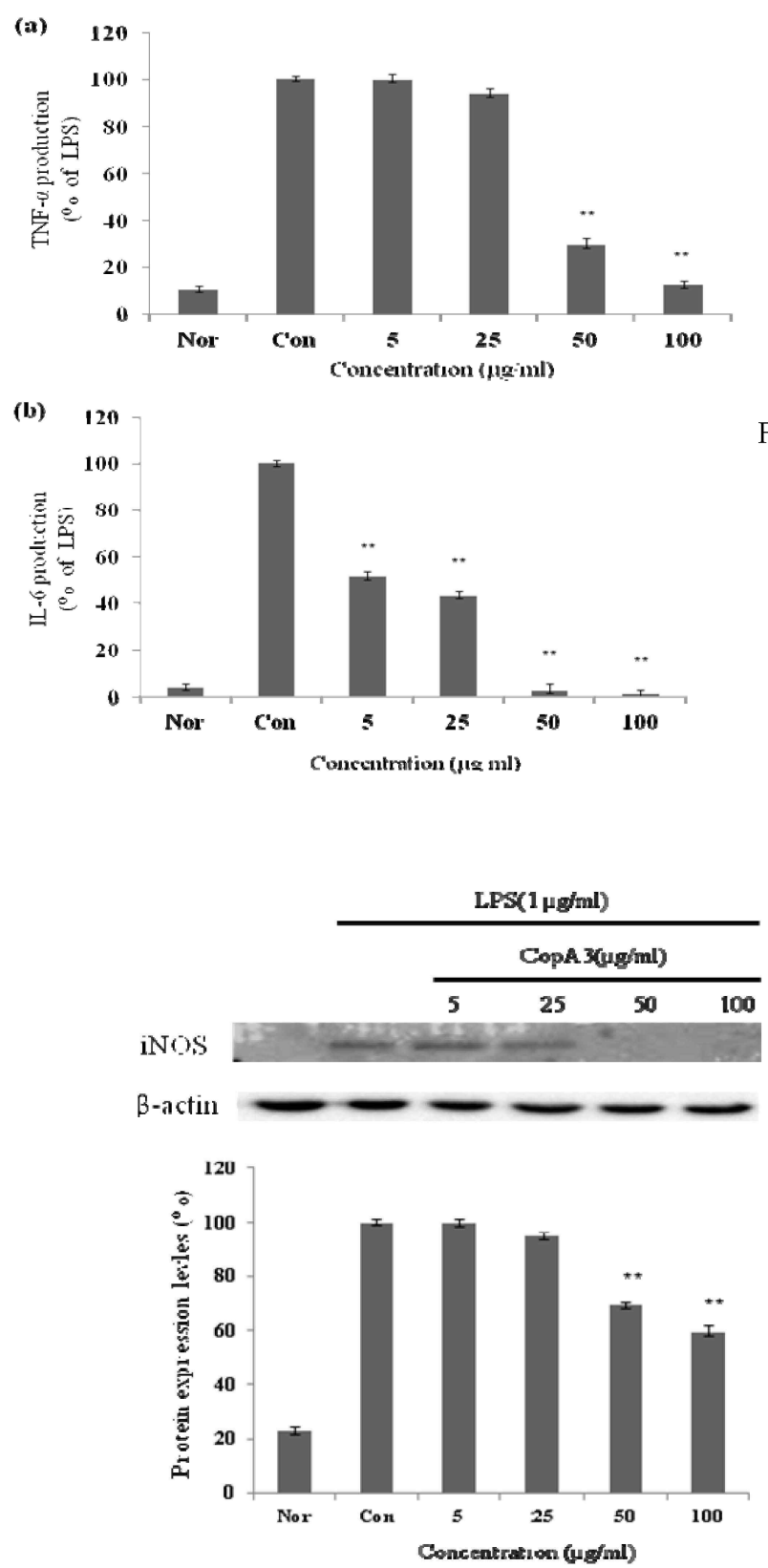

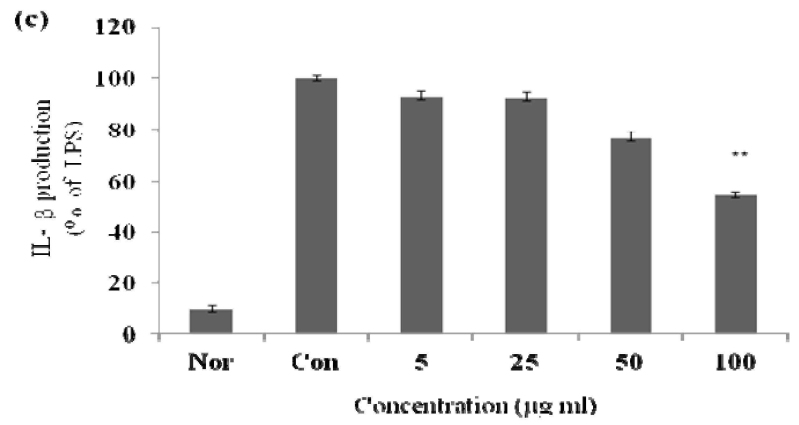

Fig. 3. Effect of CopA3 on the production of cytokines stimulated by LPS. Production of TNF-a (a) IL-6 (b), IL-1ß (c) were measured in the medium of Raw 264.7 cells cultured with LPS $(1 \mu \mathrm{g} / \mathrm{ml})$ in the presence or absence of CopA3 for $24 \mathrm{hr}$. The amount of TNF-a was measured by immunoassay as described in materials and methods. Nor: LPS not induced group, Con: LPS induced group. Data represent the mean \pm S.D. with three separate experiments. One-way ANOVA was used for comparisons of multiple group means followed by t-test (significant as compared to control. ${ }^{*} p<0.05,{ }^{* *} p<0.01$ ).

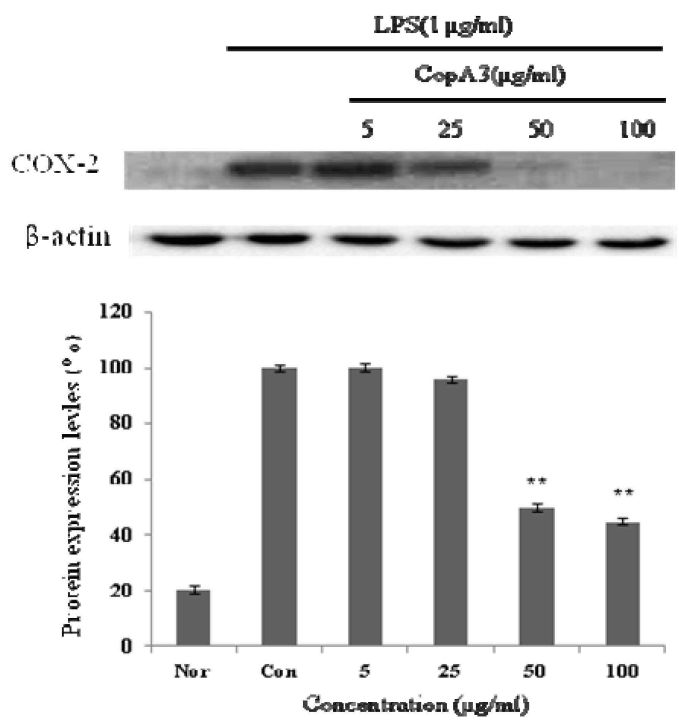

Fig. 4. Inhibitory effects of CopA3 on the protein levels of iNOS and COX-2 in Raw 264.7 cells. Raw 264.7 cells $\left(5 \times 10^{5}\right.$ cells $\left./ \mathrm{ml}\right)$ were pre-incubated for $24 \mathrm{hr}$, and the cells were stimulated with lipopolysaccharide $(1 \mu \mathrm{g} / \mathrm{ml})$ in the presence of complex extracts sample $(5,25,50,100 \mu \mathrm{g} / \mathrm{ml})$ for $24 \mathrm{hr}$. Nor: LPS not induced group, Con: LPS induced group. Data represent the mean \pm S.D. with three separate experiments. One-way ANOVA was used for comparisons of multiple group means followed by t-test (significant as compared to control. ${ }^{*} p<0.05$, ${ }^{* *} p<0.01$ ).

면 장시간 동안 다량의 $\mathrm{NO}$ 를 생성하며, 생성된 $\mathrm{NO}$ 는 혈관 투과성, 부종 등의 염증 반응을 촉진시킬 뿐만 아니라 염증매 개체의 생합성을 촉진하여 염증을 심화시키는 것으로 알려져 있다 $[12,20] . \mathrm{NO}$ 의 생성에는 NO synthase (NOS)가 작용하게 되는데, constitutive $\mathrm{NO}$ synthase (cNOS)와 iNOS 중 자극에 유도된 iNOS의 경우 오랜 기간 동안 다량의 $\mathrm{NO}$ 를 생성하고, 생성된 $\mathrm{NO}$ 는 guanyl cyclase의 활성과 동시에 세포독성을 나
타내게 된다. 따라서 NO로 유도 되어진 RAW 264.7 cell에서 iNOS의 protein level의 감소를 확인으로서 항염증 효과를 기 대할 수 있으며, 또한 세포와 같은 macrophage 따른 monocyte에서 TNF-a, IL-6 와 같은 proinflammatory cytokine을 증가시키는 요인 중 하나인 COX-2의 protein level의 감소를 이끌어 냄으로서 항염증 효과를 기대할 수 있다[19]. CopA3에 의한 NO 생성 저해 기전을 확인하기 위해 western blot을 실 
시하여 iNOS의 단백질 발현을 측정 하였으며, western blot을 이용하여 COX-2의 발현을 측정하였다. 그 결과 LPS에 의해 증가된 $\mathrm{iNOS}$ 와 COX-2의 단백질 발현량이 농도 의존적으로 유의성 있게 감소되었다. $\beta$-actin의 band density 비율에 따라 $\mathrm{iNOS}$ 단백질 생성을 $41 \%$ 와 COX-2의 단백질 발현을 $56 \%$ 저 해함을 확인 하였다(Fig. 4). 이를 통해 CopA3는 iNOS, COX-2 의 생성을 저해하는 것을 확인할 수 있었다.

\section{감사의 글}

본 논문은 농촌진흥청 동물유전체육종사업의 일환으로 수 행된 연구결과의 일부이며 이제 깊은 감사를 드립니다.

\section{References}

1. Aggarwal, B. B. 2003. Signaling pathways of the TNF superfamily: a double-edged sword. Nat Rev Immunol 3, 745-756.

2. Bang, H. S., Lee, J. H., Kwon, O. S., Na, Y. E., Jang, Y. S. and Kim, W. H. 2005. Effects of paracoprid dung beetles (Coleoptera:Scarabaeidae) on the growth of pasture garbage and on the underlying soil. Applied Soil Ecology 29, 165-171.

3. Bornemissza, G. F. and Williams, C. H. 1970. An effect of dung beetle activity on plant yield. Pedobiologia 10, 1-7.

4. Delgado, A. V., McManus, A. T. and Chambers, J. P. 2003. Production of tumor necrosis factor-alpha, interleukin 1-beta, interleukin 2, and interleukin 6 by rat leukocyte subpopulations after exposure to substance. Neuropeptide 37, 355-361.

5. Fincher, G. T. 1981. The potential value of dung beetles in pasture ecosystems. J Ga Entomol Soc 16, 316-333.

6. Hwang, J. S., Lee, J., Kim, Y. J., Bang, H. S., Yun, E. Y., Kim, S. R., Suh, H. J., Kang, B. R., Nam, S. H., Jeon, J. P., Kim, I. and Lee, D. G. 2009. Isolation and characterization of a defensin like peptide (Coprisin) from the dung beetle, Copris tripartitus. Int J Pept DOI: 10.1155/2009/136284.

7. Higuchi, M., Higashi, N., Taki, H. and Osawa, T. 1990. Cytolytic mechanism of activated macrophases. Tumor necrosis factor and L-arginine-dependent mechanism acts as synergistically as the mafor cytolytic mechanism of activated macrophages. $J$ Immunol 144, 1425-1431.

8. Tizard, I. R. and Schubot, R. M. 2004. Veterinary immunology : An introduction. W. B. Saunders Company. U.S.

9. Hwang, J. S., Lee, J., Kim, Y. J., Bang, H. S., Yun, E. Y., Kim, S. R., Suh, H. J., Kang, B. R., Nam, S. H., Jeon, J. P., Kim, I. and Lee, D. G. 2009. Isolation and characterization of a defensing-like peptide (Coprisin) from the dung beetle, Copris tripartitus. Int J Pept 136.

10. Kang, B. R., Kim, H., Nam, S. H., Yun, E. Y., Kim, S. R., Ahn, M. Y., Chang, J. S., and Hwang, J. S. 2012. CopA3 peptide from Copris tripartitus induces apoptosis in human leukemia cells via a caspase-independent pathway. $B M B$ Reports 45, 85-90.

11. Kang, J. K., Hwang, J. S., Nam, H. J., Ahn, K., Seok, J. H., and Kim, S. K. 2011. The insect peptide Coprisin prevents Clostridium difficile-mediated acute inflammation and mucosal damage through selective antimicrobial activity. Antimicrob Agents Chemother 55, 4850-4857.

12. Kim, R. G., Shin, K. M., Chun, S. K., Ji, S. Y., Seo, S. H., Park, H. J., Choi, J. W. and Lee, K. T. 2002. In vitro anti-inflammatory activity of the essential oil from ligularia fischeri var. spiciformis in murine macrophage Raw 264.7 cells. Yakhak Hoeji 46, 343-347.

13. Lee, Y. S., Kim, H. S., Kim, S. K. and Kim, S. D. 2000. IL-6 mRNA expression in mouse peritoneal macrophages and NIH3T3 fibroblasts in response to Candida albicans. $J$ Microbiol Biotech 10, 9-15.

14. Lee, A. K., Sung, S. H., Kim, Y. C. and Kim, S. G. 2003. Inhibition of lipopolysaccharide inducible nitric oxide synthase, TNF- $a$ and COX-2 expression by sauchinone effects on $\mathrm{I}-\mathrm{kBa}$ phosphorylation, $\mathrm{C} / \mathrm{EBP}$ and AP-1 activation. British J Pharmacol 139, 11-20.

15. Mori, M. 2007. Regulation of nitric oxide synthesis and apoptosis by arginase and arginine recycling. J Nutr 137, 1616-1620.

16. Palmer, R. M., Ashton, D. S. and Moncada, S. 1988. Vascular endothelial cells synthesize nitric oxide from L-arginine. Nature 333, 664-666.

17. Park, D. S., Yoo, M. A., Xu, M. Z., Yu, H. N., Kim, J. R., Jeong, T. S. and Park, H. Y. 2004. Original articles : Screening of anti-atherogenic substances from insect resources. Korean J Pharmacogn 35, 233-238.

18. Park, K. T. and Lee, J. S. 1998. Review on insect resources for medical use in kangwon Province. Korean J Apiculture 13, 79-92.

19. Suh, Y. J. 2002. Anti-tumor promoting potential of selected spice ingredients with antioxidative and anti-inflammatory activities.: A shor review. Food Chem Toxicol 40, 1091-1097.

20. Tezuka, Y., Irikawa, S., Kaneko, T., Banskota, A. H., Nagaoka, T., Xiong, Q., Hase, K. and Kadota, S. 2001. Screening of chinese herbal drug extracts for inhibitory activity on nitric oxide production and identification of an active compound of zanthoxylum bungeanum. J Ethnopharmacol 77, 209-217.

21. Weisz, A., Cicatiello, L. and Esumi, H. 1996. Regulation of the mouse inducible-type nitric oxide synthase gene promoter by interferon- $\gamma$, bacterial lipopolysaccharide and NG-monomethyl-L-arginine. Biochem J 316, 209-215.

22. Willoughby, D. A. 1975. Human arthritis applied to animal models. Towards a beter therapy. Annals of the rheumatic disease. Ann Rheum Dis 34, 471-478.

23. Won, S. J., Park, H. J. and Lee, K. T. 2008. Inhibition of LPS induced iNOS, COX-2 and cytokines expression by slidroside through the NF- $\mathrm{kB}$ inactivation in RAW 264.7 cells Korean J Pharmacogn 39, 110-117.

24. Yun, H. J., Heo, S. K., Lee, Y. T., Park, W. H. and Park, S. D. 2008. Anti-inflammatory effect of Evodia Officinalis DODE in mouse macrophage and human vascular endotherial cells. Korean J Herbology 23, 29-38. 
초록 : 애기뿔소똥구리 유래 CopA3합성 펩타이드의 항염증 효능에 관한 연구

김현정 ${ }^{1,2} \cdot$ 김동희 $\left.\right|^{3} \cdot$ 이진영 $\cdot$ 황재삼 ${ }^{5} \cdot$ 이준하 ${ }^{5} \cdot$ 이슬기 ${ }^{1} \cdot$ 정현국 ${ }^{1} \cdot$ 안봉전 ${ }^{4}$

( ${ }^{1}$ 대구한의대학교 화장품약리학과, ${ }^{2}$ 허브누리 기술연구소, ${ }^{3}$ 한국한방산업진훙원, ${ }^{4}$ 호서대학교 한방화장품과 학과, ${ }^{5}$ 국립농업과학원 농업생물부)

CopA3를 이용하여 피부 염증에 대하여 연구를 하였다. 산화질소와 cytokine의 생산은 면역세포의 대표적인 염증인자이다. 세포는 LPS 처리 후 한 시간 뒤에 CopA3를 처리하였다. 세포 독성이 나타나지 않는 농도인 5, $25,50,100 \mu \mathrm{g} / \mathrm{ml}$ 를 사용하였다. CopA3는 NO, TNF-a, IL-1 $\beta$, IL-6, iNOS, COX-2의 생성을 저해 시켰다. iNOS와 $\mathrm{COX}-2$ 역시 $100 \mu \mathrm{g} / \mathrm{ml}$ 의 농도에서 각각 $54 \%, 65 \%$ 가 저해가 되었다. 게다가 CopA3는 염증성 사이토 카인인 TNF-a, IL-13, IL-6의 생성을 감소 시켰다. 이러한 결과로 CopA3는 염증 예방과 치료에 효과적임을 확인 할 수 있었다. 